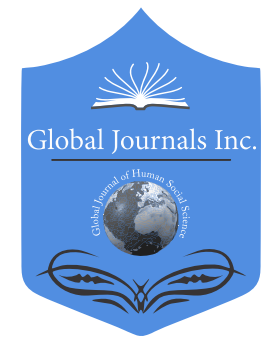

GLOBAL JOURNAL OF HUMAN-SOCIAL SCIENCE: A

ARTS \& HUMANITIES - PSYCHOLOGY

Volume 20 Issue 2 Version 1.0 Year 2020

Type: Double Blind Peer Reviewed International Research Journal

Publisher: Global Journals

Online ISSN: 2249-460x \& Print ISSN: 0975-587X

\title{
Indian Idols Drinking Milk: Understanding the Phenomenon and its Implications for Social Reform
}

By Ramadhar Singh

Ahmedabad University

Abstract- The mass media have occasionally been reporting miracles such as stone idols sipping milk or bleeding in India. The author argues for viewing such irrational happenings as the examples of the social psychological phenomenon of conformity to the group norms (i.e., informal, unwritten prescriptions of what the group might think to be right and desirable). By identifying people as likely (1) sources of accurate information and (2) standards of desirable behaviors in a given situation, it is proposed that a shift from conformity to the norms to compliance to the laws might be helpful in building a New India.

Keywords: conformity, compliance, information, miracle, norms, pressure, reform, scientific.

GJHSS-A Classification: FOR Code: 190499

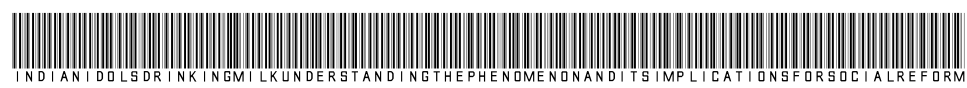

Strictly as per the compliance and regulations of:

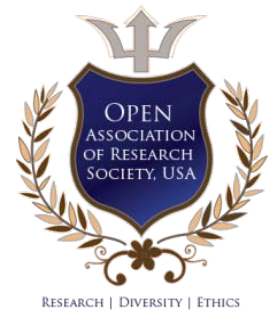

(C) 2020. Ramadhar Singh. This is a research/review paper, distributed under the terms of the Creative Commons AttributionNoncommercial 3.0 Unported License http://creativecommons.org/licenses/by-nc/3.0/), permitting all non-commercial use, distribution, and reproduction in any medium, provided the original work is properly cited. 


\title{
Indian Idols Drinking Milk: Understanding the Phenomenon and its Implications for Social Reform
}

\author{
Ramadhar Singh
}

Abstract- The mass media have occasionally been reporting miracles such as stone idols sipping milk or bleeding in India. The author argues for viewing such irrational happenings as the examples of the social psychological phenomenon of conformity to the group norms (i.e., informal, unwritten prescriptions of what the group might think to be right and desirable). By identifying people as likely (1) sources of accurate information and (2) standards of desirable behaviors in a given situation, it is proposed that a shift from conformity to the norms to compliance to the laws might be helpful in building a New India.

Keywords: conformity, compliance, information, miracle, norms, pressure, reform, scientific.

\section{Indian Idols Drinking MilK}

n the early morning of September 21, 1995, a Hindu priest in the temple of Lord Ganesh in New Delhi witnessed the stone idol sipping milk from a spoon. Those who heard of the miracle rushed to their adjacent temples across India and observed the same. Experiences of people of Hindu religion across the globe were no different. ${ }^{1}$

Comparable miracles have recently been reported in case of idols in other temples as illustrated by the following news:

Savan 2019 Miracle in Lord Shiva Temple Nandi and Ganesh Idol Drink Milk

Amar Ujala, June 29, 2019²

Lord Shiva ... Deity Nandi's Idols Drinking Spoonful of Milk? You Decide

India TV. News, June 29, $2019^{3}$

The Constitution of India envisages developing "the scientific temper [emphasis added]... and the spirit of inquiry and reform [emphasis added]" as one of the fundamental duties of the people of Republic of India (Basu, 1993, p. 131). In science, an observable occurrence is called phenomenon. Does the news about stone or metal idols sip milk then qualify to be a phenomenon? If the phenomenon is different from the news reports or the individual beliefs, how can social scientific inquiry unravel its possible mechanisms and inform subsequent social reforms and policy intervention in India?

Author: Ahmedabad University, India. e-mail: singhr@ahduni.edu.in
Academics from the Indian Institute of Technology and the Tata Institute of Fundamental Research in Mumbai, Maharashtra declined to comment on such "religious matters" although such occurrences were at odds with their espoused scientific temper. However, Prabir Ghosh-a Kolkata based rationalistcalled such reports as absurd: "I can prove that it is no miracle." ${ }^{4}$ Nevertheless, the news report continued to attract contrasting views from people of different groups and faiths. In this article, the author-an experimental social psychologist-first construes the mass perception of irrational happenings as conformity to the norms (Asch 1951, 1952; Sherif 1936, 1937) and then unravels the possible mechanisms underlying this phenomenon to draw implications for social change in India.

\section{Physical Versus Social Reality}

Humans tend to pursue truth. Toward this goal, they first rely on physical evidence. For example, one can confirm that the sun rises in the east or the west by getting up early in the morning and checking the direction. Similarly, one can determine one's height through a measuring tape and weight through a weighing machine. These yardsticks supposedly provide accurate information about physical reality.

However, physical standards are not so readily available for one's perceptions, attitudes, and opinions. What is the future of opposition parties in India? Is the global recession imminent? Is January 14, Makar Sakranti, the best day to take a holy dip in the Ganges? Should one worship Lord Shiva or Vishnu? Is the Government of India (GOI) correct in amending the citizenship act? To validate answers to these questions, one has to turn to other people (Singh et al. 2017). What others think, feel, and do constitute social reality (Festinger 1950, 1954). Thus, one evaluates the correctness of one's perceptions, thoughts, and behaviors relative to those of peers (Festinger 1954).

\section{Social Influence}

In a meeting, clapping by one person leads others to clap and laughter by one person makes others laugh. On the road, when one driver blows horns or spits, others mimic. The demonstrations against the citizenship amendment act of the GOI in Assam led to 
similar and even violent demonstrations and protests across the nation. ${ }^{5}$ Such examples of following the herd are evident in the contemporary hair styles, fashions, and how people talk over their mobile phones.

Why do people get influenced by statements and deeds of peers? Believing requires neither time nor effort but disbelieving demands both. Worse, disbelieving does not close the search of truth. In contrast, interpreting what peers say as possibly true and what they do as possibly desirable in a given situation completes the pursuit of truth. Thus, people tend to perceive, feel, and act in ways others do, illustrating conformity to the emergent norms.

\section{Two Classic Social Psychological EXPERIMENTS ON CONFORMITY}

\section{a) Autokinetic effect}

The autokinetic effect is a perceptual illusion in which an otherwise stationary point of light projected in a dark room appears to be moving. Social psychologist Sherif $(1936,1937)$ hypothesized that the agreement to estimated distance moved by the stationary light would be more when the perceiver is in a group than when he is alone.

To test the foregoing hypothesis, Sherif first asked the participants individually to estimate the distance that the light had moved. As expected, the individual estimates were very different. When the participant was placed in a group of two other persons and they were asked to announce their estimates publicly, the judgments of distance moved converged by the third session. That is, individual participants agreed with each other about the distance moved by the stationary point of light.

The norm of autokinetic effect developed in the group was also internalised by the participants. Even while reporting (a) individually, (b) after a year of the original experiment, and (c) in other groups of people, those participants adhered to their respective original groups' estimates. Given that there was no peer pressure for conformity at all under these three circumstances, the influence of the original group on them was interpreted to be purely informational. That is, peers essentially served as sources of information about what was the true movement in the otherwise stationary point of light.

\section{b) Pressure to go along}

To get along, people go along with others. What others say and do thus put subtle peer pressure to conform. To demonstrate this mechanism, social psychologist Asch $(1951,1952)$ conducted another experiment. In a given session on perceptual judgments, he showed SIX confederates and ONE participant two cards such as on the left and right sides below:

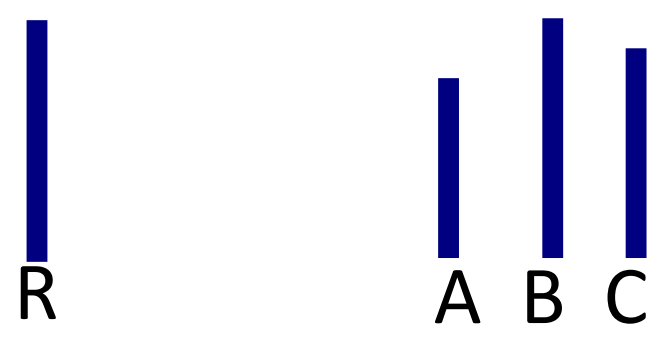

\section{Figure 1: Stimuli adapted from S. Asch (1951).}

The participants had to tell whether Bars A, B, or $\mathrm{C}$ of the right card matched with the reference bar $(\mathrm{R})$ of the left card. The individual participants never erred in matching Bar B with Bar R.

There were two experimental manipulations in a group setting. First, the seating arrangements were such that the confederates of the experimenter always spoke before the participant. Second, the confederates initially gave a variety of answers to eliminate suspicion in the participant and then incorrect responses in a preplanned manner. For example, all the six confederates would say Bar A or C equals to Bar R. The point of interest lied in showing that the participant might conform to the opinion of the incorrect majority. As expected, $76 \%$ of the participants conformed on at least one trial and $50 \%$ of them conformed on more than half of the trials of the experiment. Overall, participants conformed to the incorrect majority on 37\% of the target trials.

\section{c) Comparison between the two experiments}

In the case of the auto-kinetic effect, participants turned to each other for information. A norm was developing about possible accuracy of estimated distance moved by the stationary point of light. Participants conformed because they believed others to be correct. In the case of perceptual judgments, in contrast, cohesiveness was critical. Participants found themselves to be under awkward pressure of going along with the incorrect majority. To get along, the participant went along with others. Findings of brainimaging research indicate that those who conform in Asch-type settings also perceive the situation as everyone else does (Berns, Chappelow, Zink, Paganoni, Martin-Skurski, \& Richards 2005). That is, the loci of conformity were in both perception and behavior.

The pressure toward conformity in a misleading group that Asch $(1951,1952)$ demonstrated is a universal phenomenon, not confined to a laboratory setting or the time period in which the experiment was originally conducted. More crucially, findings related to conformity were robust across 130 experiments conducted at different points of time across 17 nations (Sunstein 2003). 


\section{d) Key understanding}

Did the stone idol of Lord Ganesh or Lord Shiva

... Deity Nandi then sip in the offered milk as reported in the Indian mass media? The answer is NO: Stone or metal idols cannot drink milk. Irrational and confusing news that prompted the author to write this article and like the following two turn people to one another to seek the possible correct information.

Shiva Temple Claims Miracle as Statue Bleeds.

Denofgeek, July 26, $2018^{6}$

Shirdi Sai Baba 'Gives Darshan' to Devotees, his Image Appears on Wall of Dwarksmai.

Zee News, July $12,2019^{7}$

To avoid appearing as religiously deviants, people agree to the misleading majority. The fear of rejection by the group is high also because Indians seem to worship more out of fear than devotion as sarcastically portrayed in the Hindi movie OMG: Oh My God! $!^{8}$ The author contends, therefore, that the so-called miracles mentioned in the endnotes can be explained by a social psychological phenomenon of conformity to the norms of erroneous perceptions and behaviors of others around us.

\section{IMPLiCATIONS FOR SCIENTIFIC INQUiRY AND SOCIAL REFORM}

The laboratory experiments of Sherif (1936, 1937) and Asch (1951, 1952) help conceptualize endorsement of irrational perceptions, feelings, beliefs, and behaviors as instances of conformity to the norms. This conceptualisation has two key implications for promoting the scientific temper and the spirit of inquiry and reform as envisaged in the Constitution of India.

The first implication pertains to the role and relevance of many traditions and festivals (e.g., Chhath, Christmas, Diwali, Dussehra, Eid Al-Fitr, Ganesh Chaturthi, Holi, Lohri, Pongal, Shivratri, to mention a few). Although they were founded on conformity to the norms of their respective periods, they have become so deeply entrenched in the human psyche that their relevance for the modern life is rarely questioned (Jacobs \& Campbell 1961; MacNeil \& Sherif 1976). For example, the aftermaths of Ganesh Chaturthi ${ }^{9}$ or Diwali ${ }^{10}$ that pose severe threats to lives, liberties, and environment have disturbingly attracted a rather limited debate and corrective action. Therefore, it is timely for all Indians to revisit and re-evaluate their herd behaviors and strive for an individual and social behavior that is more aligned to the Constitution of India.

The second implication of conformity to the norms is for the formulation and implementation of new policies. Participants in the Sherif $(1936,1937)$ experiment viewed others as sources of information. Those in the Asch $(1951,1952)$ experiment displayed "motivation not to stick out" (Sleek, 2019, p. 10). The participants were strangers to one another. There was no chance that they would meet again. Nonetheless, the information from the group and the motivation to go along with the group had tremendous impact on their judgments and behaviors. If the state and national policies are now directed at demanding compliance to the laws, the dream of New India will be served better. ${ }^{11}$ In fact, the information given and the compliance desired should be simple to understand and implement. The two recent examples of such policy formulation are compliance to submission of income tax returns ${ }^{12}$ and the new motor vehicle rules. ${ }^{13}$

To the above, it should be added that the Internet, television, and other popular media should assume the further responsibility of playing a constructive role in constructing the NEW REALITY in the nation. They should highlight what is scientifically accurate and socially desirable in the current period but refrain from propagating news that foster blind faith and behaviors that are easy to conform to (e.g., gimmicks to improve upon one's lot through astrology, fasting, gem rings, horoscope, raksha sutra, religious lockets, tabij, witchcrafts, etc.).

\section{Conclusion}

In sum, drinking of milk by the idols in India is a social psychological phenomenon of conformity to the emergent norms instead of a miracle by the god. People adhere to such irrational cognition because others serve as sources of likely accurate information and of signals of likely desirable behaviors. The extant knowledge of these two mechanisms underlying conformity to the norms can now be used to demand compliance to the laws and rules formulated by the legitimate authorities and followed by most citizens. Such strategies by social institutions have been effective in regulating perceptions and behaviours across the globe (Blair, Littman, \& Paluck 2019). It is high time for psychologists in India to study the new norms and for the media to give them the much needed support in shaping the new psyche of India.

\section{ACKNOWLEDGEMENT}

Thanks are due to Neeraj Pandey for searching some of the sites reported in the endnotes, and Prafull Anubhai, Naureen Bhullar, Kumar Rakesh Ranjan, and Jai B. P. Sinha for their constructive comments on early versions of this article.

\section{References Références Referencias}

1. Asch, Solomon E. (1951). Effects of Group Pressure upon the Modification and Distortion of Judgments. In Harold Guetzkow (Ed.) Groups, leadership, and men (pp. 177-190). Pittsburgh, PA: Carnegie Press. 
2. Asch, Solomon E. (1952). Social psychology. Englewood Cliffs, NJ: Prentice-Hall. doi: 10.1037/ 10025-000

3. Blair, Graeme, Rebecca Littman, and Elizabeth Levy Paluck (2019). Motivating the adoption of new community-minded behaviors: An empirical test in Nigeria. Science Advances, 5 (3), Article EAAU S5175. Doi:10.1126./sciadv.aau5175.

4. Basu, Durga Das (1993). Introduction to the Constitution of India (15th ed.). New Delhi: Prentice Hall of India.

5. Berns, Gregory S., Jonathan Chappelow, Caroline F. Zink, Giuseppe Paganoni, Megan F. MartinSkurski, and Jim Richards (2005). Neurobiological correlates of social conformity and independence during mental rotation. Biological Psychiatry, 58(3), 245-253.

6. Festinger, Leon (1950). Informal social communication. Psychological Review, 57(5), 271-282.

7. Festinger, Leon (1954). A theory of social comparison processes. Human Relations, 7(2), 117-140.

8. Jacobs, Richard C., and Donald T. Campbell (1961). Transmission of an arbitrary social tradition. Journal of Abnormal and Social Psychology, 62(3), 649-658.doi.org/10.1037/h0044182

9. MacNeil, Mark K., and Muzafer Sherif (1976). Norm change over subject generations as a function of arbitrariness of prescribed norms. Journal of Personality and Social Psychology, 34(5), 762-773. doi.org/10.1037/0022-3514.34.5.762

10. Sleek, Scott (2019). Renewing the new normal: Betsy Levy Paluck on norms and how to change them. Observer, 12(July/August), 9-11.

11. Sherif, Muzafer (1936). The psychology of social norms. Oxford, England: Harper.

12. Sherif, Muzafer (1937). An experimental approach to the study of attitudes. Sociometry, 1(1), 90-98.

13. Sunstein, Cass R. (2003. Why societies need dissent. Cambridge: Harvard University Press.

14. Singh, Ramadhar, Duane T. Wegener, Krithiga Sankaran, Naureen Bhullar, Karen Q. P. Ang, Pauline J. L. Chia, Xinyi Cheong, and Fu wei Chen (2017). Attitude similarity and attraction: Validation, positive affect, and trust as sequential mediators. Personal Relationships, 24(2), 203-222. DOI: 10. 1111/pere.1278.

Endnotes

1. Retrieved on August 5, 2019 from https://www.bbc.com/ news/av/magazine-38301718/the-milk-miracle-that-brought-indiato-a-standstill.

2. Retrieved on September 21, 2019 from http://theory.tifr.res.in/ bombay/leisure/trivia/ganapati-milk.html

3. Retrieved on August 5, 2019 from https://www.amarujala. com/dehradun/sawan-2019-miracle-in-lord-shiva-temple-nandiand-ganesh-idol-drink-milk?pageld=1.
4. Retrieved on August 5, 2019 from https://www.indiatvnews. com/news/india-lord-shiva-his-gate-guardian-deity-nandi-s-idoldrinking-spoonful-of-milk-you-decide-538987.

5. Retrieved on December 22, 2019 from https://www. thehindubusinessline.com/news/national/anti-caa-protestinternet-shut-down-in-parts-of-delhi/article 30346740.ece

6. Retrieved on August 5, 2019 from https://www.denofgeek. com/us/culture/occult/275204/shiva-temple-claims-miracle-asstatue-bleeds.

7. Retrieved on August 5, 2019 from https://zeenews. india.com/maharashtra/shirdi-sai-baba-gives-darshan-todevotees-his-image-appears-on-wall-of-dwarkamai2218672.html.

8. Hindi Movie: OMG-Oh My God! (2012).

9. Retrieved on September 18, 2019 from https://www. youthkiawaaz.com/2016/09/pollution-after-ganesh-chaturthi/.

10. Retrieved on September 18, 2019 from https://www. deccanchronicle.com/nation/current-affairs/091118/ hyderabadhigh-pollution-noise-recorded-on-diwali.html.

11. Retrieved on September 18, 2019 from https://www. livemint.com/politics/news/narendra-modi-pushes-for-dialoguebreaking-language-barriers-and-new-india-1567147701249.html.

12. Retrieved on September 18, 2019 from https://www. moneycontrol.com/news/business/itr-filing-2019-over-5-65-crincome-tax-returns-filed-as-deadline-ended-on-aug-31-4394791. $\mathrm{html}$.

13. Retrieved on September 18, 2019 from https://time sofindia.indiatimes.com/city/ahmedabad/ahmedabad-hefty-finesdrive-nearly-1-lakh-to-mass-transport/ articleshow/71176576.cms 